DOI: 10.1515/jolace-2015-0027

\title{
Queering gender in contemporary female Bildung narrative
}

\author{
Soňa Šnircová \\ Pavol Jozef Šafárik University, Slovakia \\ sona.snircova@upjs.sk
}

\begin{abstract}
The paper explores, in the context of feminist discussions about the Bildungsroman, a contemporary British novel that offers shocking images of female coming of age at the turn of the millennium. Queering gender and introducing male elements into the heroine's process of maturation, the analysed novel appears to raise questions about the continuous relevance of the feminist distinction between male and female version of the genre. The paper however argues that although significantly rewriting both female Bildung and pornographic narratives, Helen Walsh's Brass can still be read as a variation of the female Bildungsroman and an example of its contemporary developments.
\end{abstract}

Keywords

female Bildugsroman, male Bildungsroman, feminism, Helen Walsh, genderqueer

\section{Introduction}

Maturation understood as the "development of an innate genetic potential under the influence of a particular geographical and cultural setting" (Summerfield and Downward, 2010, p. 2) is a relatively recent concept promoted within the humanist tradition which, from the eighteenth century onwards, has shaped the modern conception of selfhood. ${ }^{1}$ The large number of literary representations of maturation that appeared during the Age of Enlightenment and the two centuries of its legacy reveal much about changing perceptions of the individual's inner world and its interaction with society. While at the beginning, the narratives of personal development possessed a high measure of thematic and structural idiosyncrasies which often formed the basis of rather narrow definitions of the Bildungsroman as a novel about a young middle-class man, the growing complexities of nineteenth- and twentieth-century society brought diversifications of the genre. The rising need to consider gender, class, ethnicity, race and sexuality in literary representations of maturation and in critical studies about them shows that both writers and critics realize that the traditional humanist idea of an internally developing individual as a unified, masculine, white, middle-class self no longer corresponds with the awareness of the complexities of personal development in the contemporary world.

\section{Female Bildung in the context of the genre}

The Bildungsroman genre originated in the eighteenth century when the idea of an individual's development through the interaction with the social environment appeared in the wider context of the Enlightenment emphasis on the importance of personal and social progress. The Enlightenment belief in

\footnotetext{
1 Watson (Spencer \& Watson, 2003) in his concise overview of the theme of maturation in British and American literature places the beginnings of maturation in fiction with John Bunyan's Pilgrim's Progress (1678), when the word progress started to mean "both movement and improvement" (p. 4). At the same time, he names Daniel Defoe as "the first great writer to find fictional ways of expressing the modern self - predominantly Protestant and middle-class, dramatic and insecure, private and social, but above all with a dynamic sense of its continuity and capacity to change and develop" (Spencer \& Watson, 2003, p. 9).
} 
the possibility of progress was deeply rooted in the philosophical assumptions about Reason, knowledge and education whose gendered nature has been noticed by female critics. Eighteenthcentury philosophy constructed the concept of Rationality as the "transcendence of the feminine" (Lloyd, 1993, p. 104), providing a conceptual basis for both association of advanced Reason with maleness and exclusion of women from the public domain. Just like society's development was assessed by the progress of Reason away from feminized Nature, the achievements of advanced Reason were measured by its capacity to leave behind the feminine, "immature stage of consciousness" (Lloyd, 1993, p. 58).

In this understanding of maturity, the public sphere plays a crucial role. As Lloyd (1993), quoting Kant, explains: "The maturity proper to enlightenment is directly connected with access to a public space in which men of learning enjoy unlimited freedom to use their own reason and 'speak in their own person"' (p. 67). To restrict this freedom in this sphere would be to 'virtually nullify a phase in man's upward progress, thus making it fruitless and even detrimental to subsequent generations'” ( $p$. 67). However, the traditional confinement of female individuals to the domestic sphere obstructed the personal development of "higher" quality available to their male counterparts and prevented them from making an autonomous contribution to the public sphere of learning and value creations. This line of philosophical thinking thus reflected the realities of the traditional divisions of female and male roles in relation to the private and public spaces and at the same time provided the conceptual reinforcement of the tradition. Assuming a woman's greater closeness to Nature, the Enlightenment philosophy did not stress so much her inferiority as her difference and the complementariness of her mind to the male one. The male capacity for developing abstract thought was complemented with female "possession of other mental traits - taste, sensibility, practical sense, feeling" (p. 76).

Inspired and shaped by the Enlightenment thought, the Bildungsroman, from its eighteenth-century German prototype, Goethe's Wilhelm Meister's Apprenticeship (1795), to its most famous nineteenthand early twentieth-century representatives in British literature (David Copperfield, Great Expectations, Sons and Lovers, The Portrait of an Artist as a Young Man), appears as a genre mainly concerned with male development. As some feminist scholars point out, this apparent maleness of the genre informs the early attempts of German critics to delineate its definition. Morgenster during a lecture in 1819 stated that "the genre was to portray the hero's Bildung (formation) in all its steps and final goal as well as to foster the Bildung of the readers" (quoted in Summerfield \& Downward, 2010, p. 1), and in 1870 Dilthey, formulating an influential definition of the genre, also spoke of "a young male hero [who] discovers himself and his social role through the experience of love, friendship, and the hard realities of life" (quoted in Labovitz, 1986, p. 2).

This tendency to associate Bildung with male hero is equally strong in the works of the critics who discuss the novel of development written in English. Howe (1930) and Buckley (1974) examine the English Bildungsroman in the context of the German tradition and derive its definitions from their discussions of nineteenth- and early twentieth-century works by mostly male authors. ${ }^{2}$ As Fraiman (1993) notices, both "Howe's rendering of Bildungsroman as 'apprentice novel'" (p. 4) and Buckley's attempts to prove "the autobiographical nature of the English Bildungsroman" by selecting the novels whose protagonists are artists (p. 8) enforce the perception of Bildung as a specifically male experience. Associating Bildung either with “'apprentice' [which] refers to a vocational practice" (p. 4) or with the "conception of artistic selfhood" (p. 8), the critics relate the process of the individual's development to the traditional domains of men. A more recent study by Moretti (2000) relates the inner development of the young protagonist in the European Bildungsroman ${ }^{3}$ to his mapping of the social space full of

\footnotetext{
2 The only significant exception is George Eliot, discussed by Buckley (1974), who reads The Mill on the Floss as "a sort of contrapuntal Bildungsroman, comparing and contrasting hero and heroine as each moves into young adulthood" (p. 97).

${ }^{3}$ Moretti's discussion includes, for example, Goethe's Wilhelm Meister, Stendhal's The Red and the Black, Dickens's David Copperfield, Fielding's Tom Jones, and Flaubert's Sentimental Education.
} 
uncertainties and contradictions and the Bildungsroman genre appears as "the 'symbolic form' of modernity" (p. 5), the era that brought the destabilization of traditional social structures and radical changes in class mobility. Although Moretti (2000) makes references to female authors (Jane Austen, Charlotte Brontë, George Eliot) and their Bildungsroman heroines (Elizabeth Bennet, Jane Eyre, Dorothea Brooke), he still relates the genre to primarily male contexts: “...the very elements that characterize the Bildungsroman as a form: wide cultural formation, professional mobility, full social freedom - for a long time, the west European middle-class man held a virtual monopoly on these, which made him a sort of structural sine qua non of the genre" (p. ix).

The recognition of the important differences between men's and women's relations to society underlies the works by the feminist critics who see the introduction of gender into the studies of the Bildungsroman as a serious precondition for expanding the definition of the genre. The first systematic approach to the novels of female Bildung appears in The Voyage in: Fictions of Female Development, which examines both classic and more modern examples of the female Bildungsroman, such as Jane Eyre, Villete, Little Women, The Awakening, Mrs. Dalloway, White Sargasso Sea and many others. Besides presenting the reader with representative texts about female Bildung, the authors also offer a criticism of male-centred approaches to the genre and try to define its female version.

Making the point that many of the constitutive elements of the protagonist's development provided by male critics of the Bildungsroman, such as formal education, independent life in the city, two love affairs and an active interaction with society, traditionally did not belong among the social options available to women, they maintain that the "heroine's developmental course is more conflicted, less direct" (Abel, Hirsch \& Langland, 1983, p. 11). At the same time, they claim that the female Bildungsroman is best described in terms of two recurrent narrative patterns: apprenticeship (to life), showing continuous development from childhood to maturity and awakening, usually realized later in life of a married woman; and in terms of thematic tensions - "between autonomy and relationship, separation and community, loyalty to women and attraction to men" (Abel, Hirsch \& Langland, 1983, pp. 11-12).

Labovitz (1986) in The Myth of the Heroine: The Female Bildungsroman in the Twentieth Century represents the voice of those who believe that the female Bildungsroman in which the protagonist's development is successfully completed could appear only in the twentieth century when "Bildung became reality for women" (p. 7). In her discussion of the works by Dorothy Richardson, Simone de Beauvoir, Doris Lessing and Christa Wolf, she mainly focuses on the recurrent patterns of their Bildung narratives, such as self-realization, sex roles, education, inner and outer directedness, career, attitudes towards marriage. The major differences between the male and female Bildungsroman, according to Labovitz (1986), include female Bildung's greater relation to "[the heroine's] life experience" than to " $a$ priori lessons to be learned" (p. 246) and replacement of the hero's grapple for social equality by the heroine's struggle for "equality between sexes" (p. 251).

Fraiman (1993) notices, just like Morreti, the Bildungsroman's ideological function and relates the narratives about male apprenticeship to the myth of bourgeois opportunity claiming that they "helped to construct the normative, middle class man whose skills and labor are his own" (p. 5). In general, she agrees that the twentieth century created more favourable conditions for the female Bildungsroman, but she focuses on four classic texts, Evelina, Pride and Prejudice, Jane Eyre and The Mill on the Floss, to show that the tendency to define the genre in terms of a single heroic figure is not useful for approaching the eighteenth- and nineteenth-century narratives about female development. She sees the major difference between the male and female versions of the genre not only in the female lack of opportunities to search for other goals in life than successful marriage and moth erhood, but also in the female protagonist's greater awareness that "personal destiny evolves in dialectical relation to historical events, social structures, and other people" (p. 10). Fraiman (1993) claims that the male Bildungsroman's focus on the protagonists' "wilful selfmaking" (p. 6) reflects the belief that the construction of self must include a high degree of individualism. On the other hand, the Bildungsroman heroines are more aware of society's influence on their self-formation. 
McWilliams (2009), dealing with more recent developments of the female Bildungsroman, notices its ambivalent position in the context of postmodern critical attacks on the humanist idea of the unified self capable of continuous progress towards improvement. The new perceptions of the self as unstable, fragmented and constantly shifting appear to have led to the decline of male versions of the genre in the second half of the twentieth century, ${ }^{4}$ but the narratives of female Bildung still work with the "idea of the cohesive self moving towards clarity and a secure place in the world" (p. 20). However, these traditional representations of the self are, according to McWilliams (2009), "rendered in a new form removed from the measured, linear development propounded in the early Bildungsroman" (p. 20).

Although the feminist concerns with gender present a valuable contribution to the studies of the genre, some female critics do not find the clear distinction between the female and male Bildungsroman productive. Ellis (1999) in her study on the British Bildungsroman between 1750 and 1850 disagrees especially with the radical rejections of the possibility of any positive female development in eighteenth- and nineteenth-century texts based on the belief that in these novels "'growing up female' has been in fact a 'growing down', 'a choice between auxiliary or secondary personhood, sacrificial victimization, madness and death"' (p. 16). Claiming that there are "striking similarities" (p. 15) between the novels about male and female Bildung, Ellis (1999) maintains that certain amount of "growing down", of certain loss of personal autonomy is an inevitable constitutive element of maturation process regardless of the protagonist's gender (p. 19).

Ellis (1999) emphasizes the common ground of the male and female Bildungsroman, giving the protagonist's agency (active involvement in one's development), self-reflection (ability to grow from one's experiences) and the protagonist's eventual reintegration with society as the most central issues in the narratives of maturation. Still, she admits to the existence of some specific aspects of the female situation when she states that the eighteen- and nineteenth-century heroine's maturation "involves learning to see herself as others see her, learning how to experience herself as the object of the other people's gaze", which enables her to preserve some autonomy by manipulating others for her own gain (p. 30). The apparent submissiveness that the heroine learns to adopt as a part of her Bildung process, Ellis (1999) suggests, is to be seen as a "form of empowerment" since it allows her to "create a manipulative form of control" (p. 33). This conflict between the heroine's apparent loss of autonomy and the actual (?) gain of feminine, manipulative control (over her husband) is seen as the typical unresolved paradox of the ambiguous endings of the classic novels of female development. As it seems, despite her questioning of the clear distinction between the male and female Bildungsroman, Ellis's argument about the heroines in the traditional British Bildungsromans adds strength to the feminist point that female development has been for centuries determined by women's greater association with the domestic sphere, which has left them "legally and socially powerless as individuals" (p. 46).

Twentieth-century developments of the female Bildungsroman have brought not only new types of heroines whose self-realization could be searched for in ways unthinkable for their eighteenth-century predecessors (equal access to formal education, active involvement in the public world of work and politics, explorations of female sexuality), but also greater thematic and formal variations of the genre. As McWilliams (2009) states, the contemporary female Bildungsroman ranges from "novels of childhood and adolescence to chronicles of transformation in middle age", usually focusing on the "moments of crisis", the turning points in the life of the heroine, "such as the onset of puberty, imminent marriage, or the prospect of children leaving home" (p. 20).

The narrative chosen for the analysis in this paper is the novel of adolescence, with its young protagonists going through several moments of crisis on her coming-of-age journey. Set at the turn of the millennium Helen Walsh's Brass appears to challenge the continuous relevance of the division between male and female Bildungsroman, as it "queers" gender and introduces male elements into the heroine's process of maturation. Mapping the main turning points in the heroines' life, however, I aim to

\footnotetext{
${ }^{4}$ Abel, Hirsch \& Langland (1983), for example, quote an opinion of Miles who claims that the male Bildungsroman "has reached its 'absolute end' in Grass's The Tin Drum" (p. 13), published in 1959.
} 
show that, despite its questioning of the gender binary, Brass can be still read as a variation of the female Bildungsroman.

\section{Queering gender in Brass}

Curry (1998), in an article on the construction of women in contemporary female fiction, notices the emergence of the "girl 'I' narrators" who "recognize that adults do not want to hear about incest, sexual activity, sexual desire, masochistic desire, and other "unladylike" language, but these girls, like their authors, no longer wish to fake their innocence, nor to preserve the innocence of the surrounding adults" (p. 97). O'Reilley, presenting the reader of Brass with explicit descriptions of her "queer" desires and casual sex with men and women, appears as one of the girls who resist "both patriarchy's constrains as well as the constraints of feminist portrayals of them as victims" (Walsh, 2004, p. 97). She creates an image of girlhood which questions both feminist assumptions about pornography as well as traditional stereotypes about gender identities. However, I intend to argue that despite its gender queering and its presentation of the heroine as a sexual predator who satisfies her "pervert" desire for schoolgirls through sexual encounters with "brass" (prostitutes), Helen Walsh's novel is still primarily a story about growing into womanhood. Although significantly rewriting both female Bildung and pornographic narratives, Brass can still be read as a variation of the female Bildungsroman and an example of its development at the end of the millennium.

The novel has in fact two narrators, nineteen-years-old Millie and her older friend Jamie, whose stream-of-consciousness monologues, presented in regular intervals, cover the two-month period that leads to the escalation of Millie's coming-of-age crisis. The choice of narrating the story in present tense and with the focus on the just lived experience, on the one hand, creates a postmodern image of identity as fluid, unstable and under constant process of construction, and, on the other, forces the reader to construct the heroine's life from scattered memories and sporadic references to the past. Millie as the narrator of her growing-up story does not possess the detached perspective that would allow her to reflect on the psychological and social conditions of her personal development in a consistent and explanatory way. Although her monologues are not devoid of brief epiphanic or reflective moments, her mind seems to be obsessed with her bodily desires and the need of their instant gratification through binge drinking, drugs and sex.

Millie grows up in a middle-class family with traditional gender role divisions. Her father is a distinguished professor at the University of Liverpool, while her mother, herself a teacher, performs the female role of caregiver: "That's what she was best at Mum. Being a Mum and a wife. Put her everything and beyond into looking after us" (Walsh, 2004, p. 250). The father, loving but unable to help Millie through the crisis of adolescence is quite eager to introduce his daughter to the dangers of the world; at first only by exposing her to the effects of wild storms during their trips to the sea, later by "sneaking [her] nips of Jamesons" (p. 63) behind her mother's back. Due to his relaxed attitude about her drinking, clubbing and entering the drug culture at the age of thirteen, the father appears as an embodiment of the-end-of-the-millennium permissive society and its failure to deal with adolescent youth. This failure is ironically emphasized by the fact that though being a writer of important sociology books on the crime and deviance in contemporary Britain, he is unable to perceive the devastating effects of his daughter's involvement with prostitutes and criminals.

The novel's central concern with the protagonist's corrupted life in the city may suggest that the twentieth-century process of women's emancipation managed to wipe out traditional differences between male and female stories of development. As feminist critics have noticed, the heroine of the classic female Bildungsroman, usually educated in the safe space of her parental or marital home, has almost no opportunity to experience the city. On the other hand, in the male Bildungsroman the city plays a crucial role:

[The protagonist] sometimes at a quite early age, leaves the repressive atmosphere of home (and also the relative innocence), to make his way independently in the city...There his real 
"education" begins, not only his preparation for a career but also - and often more importantly his direct experience of urban life. The latter involves at least two love affairs or sexual encounters, one debasing, one exalting, and demands that in this respect and others the hero reappraises his values. (Buckley, 1974, p. 17)

To Millie, who dismisses the academic world as sterile and hypocritical, the city also provides the "real" life experience, and as a Bildung narrative protagonist she encounters the physical and moral corruption that her nineteenth-century male predecessors could not even imagine. ${ }^{5}$ Still, the heroine's "male" encounter with the city does not overshadow the fact that what Brass presents is primarily a female Bildung process. Firstly, Millie never really leaves her paternal home and, as her working-class friend Jamie notices, her movements in Liverpool's underworld are protected by her middle-class privilege and father's money. She runs to the city to satisfy her desires, not to search for an independent life on her way to maturity.

Secondly, her encounter with the city and its corruptions is not a result of her conflict with the father, which is a typical situation in the narratives of male Bildung, but, on the contrary, of her intense emotional affiliation with the male parent after the marital breakup. According to Buckley (1974), the typical male Bildung includes "the loss of the father, either by death or alienation" which "usually symbolizes or parallels a loss of faith in the values of the hero's home and family" (p. 19). This "defection of the father becomes accordingly the principle motif force in the assertion of the youth's independence" (p. 19). The parents' divorce, on the one hand, causes Millie's loss of faith in home - the faith in monogamy and happy families - but, on the other, it intensifies her affection for the adored father. Millie naively believes that her sexy father is "utterly, adoringly oblivious to the starving adulation [of female students] he so innocently accrues" (Walsh, 2004, p. 88), not realizing that her suddenly developed "pervert" desire for schoolgirls mimics the father's inappropriate desire for his young students. Millie's discovery of the pleasure derived from pornographic images of women, her "voyage into the arcane alter ego of men's sexuality" (p. 199) during the emotional turmoil of the marital crisis suggests that she adopts the male position as a subconscious rejection of the mother who "betrayed" them when she left home. Thus far from going through a conflict with her father, Millie is crucially shaped by the mother/daughter relationship, which is "a key element in the female Bildungsroman" (Gamallo, 1998, p. 121). This draws attention to Chodorow's point, noticed by Gamallo (1998) in relation to another Bildungsroman heroine with queer identity, that "women's sexual difference stems primarily from their identification with their mothers (and not with their fathers, as in the case with boys)" (p. 121). Millie's rejection of the mother indeed seems to prevent her from evolving into "a healthy uncomplicated heterosexual" (p. 199), while the final identification with her, as I show later, has a significant influence on the heroine's maturation into womanhood.

The pornographic passages that Walsh creates to attack "Andrea Dworkin feminism and ... its homophobic inference that there are only two genders or sexualities, and all men are perpetrators and all women are victims" (Helen Walsh, 2008) introduce the queering of gender that may raise questions about the need to distinguish between male and female Bildung. Walsh's portrait of the protagonist with bisexual behaviour makes an acceptable point about female individuals' ability to adopt even the most "extreme" male subject positions such as, the indulgence in pornography or the enjoyment of sexual preying on vulnerable women. The reader is constantly reminded of this by Millie's masculine objectification of female bodies or by pornographic scenes, typically associated with male imagination: a brief sexual encounter with a child prostitute in a graveyard, the search for the fleeting moment of sexual satisfaction in the arms of a whore infected with gonorrhoea, even a rape of a drunken schoolgirl in a pub's toilet. However, what the reader receives as an undercurrent message is that Millie's masculine desire to "violate" the innocent bodies of young girls, finally realized in the rape scene, is

\footnotetext{
${ }^{5}$ As Buckley's study (1974) suggests, although urban life of the male hero usually includes sexual experience, the
} city is in traditional Bildungsroman more associated with corrupting power of money than corruption of the body. 
aligned to her need to violate the image of her own innocent girlhood, whose loss keeps torturing her mind. Millie comes close to grasping the connection when during a lustful watching of schoolgirls, a moment of revelation comes: "And it's then that it pricks me. The cold weight in my tummy. I know what it's about now. It's the realisation that I was once fourteen and carefree. That I was once a kid" (Walsh, 2004, p. 126). When later, after the rape scene, Millie wonders drugged and disorientated in a dangerous part of Liverpool, turning herself into an easy prey for rapists, she again has a moment of revelation that there is no great difference between her and the schoolgirls who "go out, get off their head and then walk home and expect their pals or Mr fucken Samaritian to look out for them" (p. 230).

In fact, despite all her "fearless", nocturnal explorations of the Red Light District, Helen Walsh's heroine appears quite often in need of male protection. Whether it is Sean who follows Millie to save her from a potential rape attack, Stan who offers help instead of robbing her during her drunken sleep on a park bench or Jamie who, from the moment he finds Millie, thirteen-year-old, in front of a club, keeps taking care of her - all these cases represent thwarted versions of "romantic chivalry", which survive in the post-feminist atmosphere of the end of the millennium. This romantic line of the plot acquires its centrality through the novel's focus on Jamie's relationship with Millie that goes through the wellknown stages of romance narratives: the initial emotional confusion of the protagonists (for years Millie and Jamie believe that they enjoy a "male" form of friendship, realized through the laddish pastimes of heavy drinking and drug-taking), the complication produced by the threat of the wrong choice of marital partner (represented by Jamie's proposal to another girl) and the lovers' final realization of the true nature of their relationship during the emotional storms of the novel's climax.

The motif of romance creates an important connection between Millie's coming-of-age story and classic female Bildung narratives, which is further strengthened by Jamie's role of male mentor, traditionally an older man who "schools [the heroine] in order to wed her" (Fraiman, 1993, p. 6). Jamie, nine years older than Millie, offers the education that she cannot find at home. Thus while her father is an egoistic womanizer whose constant sexual affairs destroy his marriage, Jamie taught Millie that "sex was much concerned with psychology as it was with physiology. It was as much about the courting of anatomy as it was the meeting of two hearts, two minds" (Walsh, 2004, p. 196). He also expresses his concern about Millie's future, urges her to grow up and not to waste the opportunities provided by her middle-class background and university education. The fact that Millie, "reared on the diet of Bronte and Austen" (p. 122), finds in Jamie a "soul mate" who satisfies her need for a relationship with a father figure (reflected in her search for and quick emotional attachment to middle-age sexual partners) also shows that she experiences an end-of-the-millennium version of the traditional female development story. As the novel's allusions reveal, Brass is, to a great extent, a conscious rewriting of the female Bildungsroman in the style of James Kelman and Hubert Selby Jr. (p. 122), whose interests, respectively, in capturing lower-class urban experience through characters' internal mental processes and "indecent" taboo subjects pervade Walsh's image of the heroine's apprenticeship in womanhood.

Helen Walsh's surface emphasis on female equality, realized through Millie's equal access to the depravity of the urban world, is in Brass combined with the undercurrent stressing the heroine's female positions in what remains a predominately male world. Even when she adopts a "male" role of a prostitutes' punter, Millie is forced to accept the female position, as she watches a male customer who is "picking up a whore" (Walsh, 2004, p. 93): “...as a man, and a man with a car, he has privileges that I can only dream of. Even if he's obese and miserable, even if she's the lowliest, more rancid wraith, I still wish I were him" (pp. 93-94). A woman's perspective can be also sensed in Millie's sorrow over the loss of belief in the possibility of monogamy and in her criticism of the hypocrisy of the family men who playing "proud husbands" and "proud fathers" hide their sick and depraved nature (p. 112). Millie's inability to admit that this criticism applies the most to her own father is a sign of her immaturity and unwillingness to lose the last connection with her innocent girlhood that the idealization of the male parent provides.

Thus when she is exposed not only to the reality of her father's "pathetic" sexual affairs with his "love-struck students" (p. 253), but also to the truth that the real cause of the marital breakup was his 
adultery with the mother's sister, Millie's much admired aunt, she experiences a crucial turning point on her way to maturity. The fact that her growing up is mainly induced by the re-living of her mother's experience of disappointment, jealousy and betrayal by the persons she loved shows that the identification with the mother plays an important part in the heroine's abandonment of childhood naivety and her willingness to accept womanhood. The return to the mother is reinforced on the level of the plot when Millie, worn out by her lifestyle and feeling dislike for "that person in the mirror" (p. 277) decides to leave the paternal home and travels to the Scottish "countryside, far, far away from the madness of the city" (p. 294) to search for her mother's help. Leaving Millie standing hopefully on the threshold of the mother's house, Helen Walsh's end-of-the-millennium story of female development leaves the reader with an open-ending conclusion and the sense that it promotes quite a traditional, Rousseauistic, belief in the healing touch of mothers and the purifying effect of (mother) nature.

\section{Conclusion}

The analysis of Helen Walsh's Brass has shown that the novel preserves important connections with traditional Bildungsroman narratives about women. It has also revealed that despite women's achievement of a high level of equality with men, including the right of equal access to the dubious joys of binging on alcohol, drugs and sex, the distinction between male and female Bildung remains useful. The heroine's process of maturation, just like the maturation of her eighteenth- and nineteenth-century predecessors, is influenced more by her life experience than formal schooling. In addition, although Millie goes through some form of experience of the "independent" existence in the city that is seen as central to the traditional male Bildung, her personal development is to a great extent dependent on the domestic sphere and her need for familial ties. Millie, who instinctively searches for the feeling of security in the circle of Jamie's family and depends on his "brotherly" mentorship, at the end hopes to shed the confusions of adolescence in the domestic space of her mother's house. The female nature of her Bildung is also emphasized by the centrality of the romantic apprenticeship motif in her coming-ofage narrative, represented not only by her acquisition of the ability to overcome her dependency on an ideal man image and recognize the right male partner, but also by acquiring an adult understanding of the relationship between men and women.

On the other hand, the central place that active sexual life has in Millie's process of maturation proves that the twentieth century brought some radical changes in the representations of female development. While the traditional Bildugsroman's hero was allowed to experience "at least two love affairs or sexual encounters" (Buckley, 1974, p. 17), its heroine's sexuality was for centuries considered to be a taboo subject, either completely unrepresentable or touched only through subtle symbolism. Helen Walsh's pornographic passages indicate the extent that the breaking of the taboo achieved at the turn of the millennium. Undoubtedly, a major difference between the classic female Bildung narrative and Walsh's novel is the latter's questioning of the gender binary not only by putting the heroine into the "male" roles of prostitutes' punter and sexual predator, but also by letting her go through "male" emotional reactions: the disdain for the prostitutes she uses to satisfy her desires, the feelings of "horror, guilt and disgust" (Walsh, 2004, p. 107) induced by a one-night stand with a whore, the rejection of the feeling of guilt by the belief that the rape victim "enjoyed it" (p. 218). Still, as I have argued, the coming-of-age process of Walsh's heroine includes some important signs of a typical female development: the conflict with mother, the emotional attachment to father/figures, the romantic involvement with man and the final return to mother (nature) as a form of accepting womanhood. This indicates that the novel can be read as a representative of the female Bildugsroman, which in its contemporary form preserves the interest in specific aspects of female development. 


\section{References}

Abel, E., Hirsch, M. \& Langland, E. (Eds). (1983). Voyage in: Fictions of female development. Hanover and London: UP of New England.

Buckley, J. H. (1974). Season of youth: The Bildungsroman from Dickens to Golding. Cambridge, Massachusetts: Harvard UP.

Curry, R. C. (1998). 'I ain't no friggin' little wimp': The girl 'I' narrator in contemporary fiction. In Saxton, R. O. (Ed). The girl: Construction of the girl in contemporary fiction by women (pp. 95-105). New York: St. Martin's Press.

Ellis, L. (1999). Appearing to diminish: Female development and the British Bildungsroman, 1750-1850. London: Associated UP.

Fraiman, S. (1993). Unbecoming women: British women writers and the novel of development. New York: Columbia UP.

Gamallo, I. C. A. (1998). Subversive storytelling: The construction of lesbian girlhood through fantasy and fairy tale in Jeanette Winterson's Oranges Are Not the Only Fruit. In Saxton, R. O. (Ed). The girl: Construction of the girl in contemporary fiction by women (pp. 119-134). New York: St. Martin's Press.

Helen Walsh: young, gifted, bold as brass (2008, March 7). The Independent. Retrieved from: http://www.independent.co.uk/arts-entertainment/books/features/helen-walsh-young-giftedbold-as-brass-792492.html

Howe, S. (1930). Wilhelm Meister and his English kinsmen: Apprentices to life. New York: Columbia UP. Labovitz, E. K. (1986). The myth of the heroine: The female Bildungsroman in the twentieth century, Dorothy Richardson, Simone de Beauvoir, Doris Lessing, Christa Wolf. New York: Peter Lang.

Lloyd, G. (1993). The man of reason: "Male" and "female" in Western philosophy. London: Routledge.

McWilliams, E. (2009). Margaret Atwood and the female Bildungsroman. Surrey: Ashgate.

Moretti, F. (2000). The way of the world: The Bildungsroman in European culture. Trans. Albert Sbragia. New ed. London/New York: Verso.

Spencer, M. M., \& Watson, V. (2003). Coming of age in children's literature: Growth and maturity in the work of Phillippa Pearce, Cynthia Voigt and Jan Mark. London: Continuum.

Summerfield, G. \& Downward, L. (2010). New perspectives on the European Bildungsroman. London: Continuum.

Walsh, H. 2004. Brass. Edinburgh: Cannongate.

\section{Contact}

Mgr. Soňa Šnircová, PhD.

Faculty of Arts, Pavol Jozef Šafárik University

Petzvalova 4, Košice, Slovakia

sona.snircova@upjs.sk 